\title{
Gorontalo
}

Journal of Public Health

Volume 3 - No. 1 - April 2020

P-ISSN: 2614-5057, E-ISSN: 2614-5065

\section{Variabilitas Iklim dengan Kejadian Demam Berdarah Dengue di Kota Tangerang}

\section{Climate Variability with Dengue Hemorrhagic Fever in Tangerang City}

\author{
Citra Puspa Juwita \\ Program Studi Fisioterapi, Fakultas Vokasi, Universitas Kristen Indonesia, \\ Jakarta Timur, Indonesia \\ email: citra.simatupang@uki.ac.id
}

\begin{abstract}
Dengue Hemorrhagic Fever (DHF) is an endemic disease of Tangerang City with fluctuating case month by month. DHF is a disease that caused by dengue virus and transmitted by Ae. Aegypti, and also have relation with climate variability conditions. This research is using secondary data with ecological study design by using time series, to see the correlations between climate variability (temperature, precipitation and humidity) with hemorarhagic dengue fever cases in Tangerang City in the period 2004-2013. This research was using univariate analysis method and bivariate analysis with correlation and linear regression. This study revealed that significant correlation between dengue hemorrhagic fever cases with climate variability; in moderate correlation which correlation between dengue hemorrhagic fever with temperature has coefficient correlation 0,314 and $p=0.004$; correlation between dengue hemorrhagic fever with precipitation has coefficient correlation 0,355 and $p=0.000$; and correlation between dengue hemorrhagic fever with humidity has coefficient correlation 0,298 and $p=0.002$. Strong correlations can be seen with a short period by year. Significant relationship on climate variability (temperature, rainfall and humidity) with the incidence of DHF period of 10 years (2004-2013) with moderate closeness.
\end{abstract}

Keywords: dengue haemorrhagic fever; humidity; precipitation; temperature

\begin{abstract}
Abstrak
Demam Berdarah Dengue (DBD) merupakan penyakit yang endemis di Kota Tangerang dengan kejadian yang berfluktuasi per bulannya. Penyakit yang disebabkan oleh virus dengue yang ditularkan oleh nyamuk Ae. aegypti ini akan tinggi ketika musim penghujan tiba dan akan berangsur-angsur menurun ketika tidak musim penghujan. Dengan menggunakan data sekunder yang tersedia, penelitian ini menggunakan desain studi ekologi, berdasarkan urutan waktu (time series) untuk melihat adakah hubungan antara variabilitas iklim (suhu, curah hujan dan kelembaban) dengan kejadian demam berdarah dengue di Kota Tangerang. Analisis yang digunakan adalah univariat dengan menggunakan distribusi frekuensi dan analisis bivariat dengan uji korelasi dan regresi linear. Berdasarkan hasil penelitian dinyatakan bahwa adanya hubungan yang bermakna antara kejadian demam berdarah dengue dengan variabilitas iklim dengan keeratan hubungan yang sedang yaitu pada hubungan antara kejadian demam berdarah dengue dengan suhu memiliki koefesien korelasi 0,314 dan nilai $\mathrm{p}=0,004$; hubungan antara kejadian demam berdarah dengue dengan curah hujan memiliki koefesien korelasi 0,355 dan nilai $\mathrm{p}=0,000$; dan hubungan antara kejadian demam berdarah dengue dengan kelembaban
\end{abstract}


memiliki koefesien korelasi 0,298 dan $\mathrm{p}=0,002$. Hubungan yang erat dapat dilihat dengan periode waktu yang pendek yaitu per tahun. Hubungan yang bermakna pada variabilitas iklim (suhu, curah hujan dan kelembaban) dengan kejadian DBD periode 10 tahun (2004-2013) dengan keeratan sedang.

Kata kunci: curah hujan; demam berdarah dengue; kelembaban; suhu

\section{PENDAHULUAN}

Pada dasarnya iklim bumi senantiasa mengalami perubahan, hanya saja perubahan iklim dimasa lampau berlangsung secara alamiah. Namun kini perubahan tersebut disebabkan oleh kegiatan manusia (antropogenik), terutama yang berkaitan dengan pemakaian bahan bakar fosil dan alih guna lahan. Virus dengue sangat sensitif terhadap kondisi lingkungan, suhu, curah hujan dan kelembaban dimana penting untuk kelangsungan hidup nyamuk, reproduksi dan pengembangan dan dapat mempengaruhi keberadaan nyamuk.

Kejadian DBD di Indonesia pada umumnya terjadi pada awal musim hujan (permulaan tahun dan akhir tahun). Hal ini dikarenakan pada musim hujan vektor penyakit demam berdarah populasinya meningkat dengan bertambah banyak sarang-sarang nyamuk diluar rumah sebagai akibat sanitasi lingkungan yang kurang bersih, sedang pada musim kemarau Ae. aegypti bersarang di bejana-bejana yang selalu terisi air seperti bak mandi, tempayan, drum dan penampungan air. Penelitian yang dilakukan di Jawa Barat dalam kurun pengamatan 2004 - 2008, didapat bahwa curah hujan berpengaruh terhadap kejadian DBD (Raksanagara dkk, 2015). Tersedianya air dalam media akan menyebabkan telur nyamuk menetas dan setelah $10-12$ hari akan berubah menjadi nyamuk. Bila manusia digigit oleh nyamuk dengan virus dengue maka dalam waktu $4-7$ hari hari kemudian akan timbul gejala DBD. Penanganan yang tidak dengan serius maka akan menyebabkan kematian, sesuai infodatin bahwa pada tahun 2017 case fatality rate (CFR) DBD di Indonesia adalah sebesar 1\% dengan kategori tinggi (Indrayani dkk, 2018).

Menurut data dinas kesehatan Provinsi Banten tahun 2018 dan 2019 didapat bahwa Kejadian demam berdarah di Banten pada tahun 2017 memiliki incidence rate (IR) 11,59 dengan CFR 0,79\%, dan di Kota Tanggerang ada 228 kasus. Pada tahun 2018 incidence rate (IR) 11,48 dengan CFR 0,86\%, dan di kota Tanggerang ada 133 kasus. Incidence rate di provinsi Banten cenderung dibawah target nasional 49 per 100.000 penduduk tetapi jika dilihat dari CFR nya maka provinsi Banten tinggi dan hampir mendekati target Nasional yaitu 1\% (Dinkes Banten, 2018; Dinkes Banten 2019).

Penelitian yang dilakukan oleh Ibarra and Lowe (2013) di pesisir Selatan Ekuador dengan melihat variabilitas iklim dan non-iklim interannual pada demam berdarah, dengan menggunakandata iklim lokal dan suhu permukaan laut Pasifik didapat bahwa curah hujan, dan suhu minimum secara positif terkait dengan demam berdarah, dengan lebih banyak kasus demam berdarah selama El Nino dengan data yang diambil pada tahun 2001 - 2010. Suhu berpengaruh pada daur hidup, kelangsungan hidup, pertumbuhan dan perkembangannya dari hewan. Adaptasi suatu spesies terhadap suatu suhu udara tertentu akan mempengaruhi sebaran geografik spesies tersebut. Siklus gonotropik atau perkembangan telur, umur, dan proses pencernaan nyamuk dipengaruhi oleh temperatur. Kondisi lingkungan dengan temperatur $27^{\circ} \mathrm{C}-$ $30^{\circ} \mathrm{C}$ dalam kurun waktu yang lama akan mengurangi populasi vektor. Penelitian Arieskha dkk (2019) dengan menggunakan uji korelasi variabilitas cuaca pada tahun 2012 - 2018 maka didapat faktor resiko dalam kejadian DBD di Kabupaten Tegal adalah suhu udara dengan $p=0,023 ; r=-0,821$. Angka 
kejadian DBD yang berfluktuatif pada penelitian terdahulu menunjukkan adanya hubungan dengan perubahan iklim maka perlu diketahui apakah kejadian DBD di Kota Tanggerang berhubungan dengan perubahan iklim.

\section{METODE}

Penelitian ini merupakan studi ekologi atau studi korelasi populasi tentang hubungan faktor iklim (suhu, curah hujan dan kelembaban) dengan jumlah kasus DBD di Kota Tangerang dalam 10 tahun (2004 - 2013). Analisis data sekunder melalui data iklim yang secara rutin dilakukan oleh Badan Metereologi dan Klimatologi Geofisika BMKG Pondok Betung dan data kejadian demam berdarah yang dikumpulkan Kementerian Kesehatan dari Dinas Kesehatan Provinsi. Populasi dalam penelitian ini adalah semua penduduk yang didiagnosa kasus DBD di Kota Tangerang yang tercatat di Kementerian Kesehatan tahun 2004 - 2013. Pada penelitian ini tidak dilakukan pengambilan sampel karena pengamatan dilakukan pada total populasi dengan unit pengamatan Kota Tangerang, Propinsi Banten.

Penentuan pasien didiagnosis DBD adalah dengan penegakkan diagnosis oleh dokter melalui anamnesis, pemeriksaan fisik dan pemeriksaan penunjang laboratorium dimana apabila demam disertai 2 atau lebih gejala penyerta seperti sakit kepala, nyeri dibelakang bola mata, pegal, nyeri sendi atau adanya ruam, dengan disertai manifestasi perdarahan leucopenia (lekosit $<5000 / \mathrm{mm}^{3}$ ), jumlah trombosit $<150.000 / \mathrm{mm}^{3}$ dan peningkatan hematokrit $5-10 \%$.

Data iklim dipantau setiap hari oleh Stasiun Meteorologi BMKG Pondok Betung yang terletak pada titik koordinat $106^{\circ} 45^{\prime} 00^{\prime \prime}-06^{\circ} 15^{\prime}$ 20,8" BT dengan metode sesuai dengan standar. Suhu udara diukur dengan termometer (Celcius) dimana setiap harinya dilakukan pengukuran oleh BMKG Pondok Betung dalam 3 tahap pengukuran (jam 7.00, jam 13.00, dan jam 18.00). Pada ketiga pengukuran per hari ini maka dibuat rata-rata untuk menilai suhu udara pada hari tersebut (Sangkertadi, 2013). Curah hujan diukur dengan penakar hujan $(\mathrm{mm})$ jenis hellman, yang setiap harinya diukur oleh BMKG Pondok Betung setiap jam 7 pagi. Pencatatan dihitung berdasarkan banyaknya air yang tertampung dalam suatu gelas ukur curah hujan, dalam satuan waktu. Gelas ukur ini dipasang dengan ketinggian $120 \mathrm{~cm}$ dari permukaan tanah sampai ke corong penakar dan luas penampang corong $200 \mathrm{~cm}$ (Sangkertadi, 2013). Kelembaban diukur dengan alat psyhrometer (\%) yang setiap harinya diukur oleh BMKG Pondok Betung pada jam 7.00, jam 13.00 dan jam 18.00, sehingga didapatkan angka jumlah uap air dalam udara (Suhardi 2012).

Analisis data yang digunakan adalah analisis univariat dan bivariat dengan uji korelasi dan regresi menggunakan uji kenormalan data. Dengan melihat keeratan hubungan, arah hubungan dan besarnya pengaruh variabilitas iklim dengan kejadian DBD. Dengan melihat pertumbuhan virus dalam tubuh nyamuk sampai pada timbulnya gejala DBD maka untuk kejadian DBD menggunakan waktu satu bulan sesudah kejadian iklim (time lag $=1$ bulan).

\section{HASIL DAN PEMBAHASAN}

\section{Variabilitas Iklim dan Kejadian Demam Berdarah Dengue}

Tabel 1. Distribusi Variabilitas Iklim dan Kejadian DBD

\begin{tabular}{lcc}
\hline \multicolumn{1}{c}{ Variabel } & Mean & SD \\
\hline Kejadian DBD (orang) & 50,8 & 44,9 \\
Suhu ( ${ }^{\circ}$ C) & 27,7 & 0,6 \\
Curah hujan (mm) & 175,7 & 137,4 \\
Kelembaban (\%) & 79,9 & 4,0 \\
\hline
\end{tabular}


Rata - rata kejadian DBD dalam periode tahun 2004 - 2013 adalah 51 orang dengan standar devisiasi 45 orang, suhu rata-rata adalah $27,7{ }^{\circ} \mathrm{C}$ dengan standar devisiasi $0,6^{\circ} \mathrm{C}$, curah hujan rata-rata adalah $175,7 \mathrm{~mm}$ dengan standar devisiasi 137,4 $\mathrm{mm}$, dan kelembaban rata-rata 79,9\% dengan standar devisiasi $4 \%$.

Tabel 2. Analisis Korelasi dan Regresi Variabilitas Iklim dengan Kejadian DBD

\begin{tabular}{cllclc}
\hline Tahun & Variabel & $\mathrm{R}$ & $\mathrm{R}^{2}$ & \multicolumn{1}{c}{ Persamaan Garis } & Nilai $p$ \\
\hline \multirow{3}{*}{$2004-2013$} & DBD* Suhu & 0,314 & 0,099 & $\mathrm{DBD}=724+(-24,4)$ suhu & 0,004 \\
& DBD* CH $^{*}$ & 0,355 & 0,126 & $\mathrm{DBD}=30,4+0,1 \mathrm{CH}$ & 0,000 \\
& DBD* RH $^{*}$ & 0,298 & 0,089 & $\mathrm{DBD}=-216,8+3,3 \mathrm{RH}$ & 0,002 \\
\hline
\end{tabular}

\section{Suhu dengan Angka Kejadian Demam Berdarah Dengue}

Suhu rata - rata pada tahun 2004 - 2013 di Kota Tanggerang berkisar 27,70 C dengan simpangan baku 0,60 C. Hasil uji korelasi dan regresi terdapat hubungan yang bermakna antara suhu dengan kejadian DBD pertahun yaitu pada tahun 2004, 2005 dan 2007 serta kejadian selama periode 10 tahun yaitu tahun 2004-2013 dengan $\mathrm{p}=0,004$, dengan koefesien korelasi $=-0,444$ dan bahwa 9,9\% kejadian DBD dapat dijelaskan dengan penurunan suhu udara. Hasil ini senada dengan yang terjadi di Jakarta Timur pada tahun 2000 - 2009 bahwa adanya hubungan signifikan $(\mathrm{p}=0,000)$ antara suhu udara dengan kejadian DBD dengan koefisien korelasi sedang dimana semakin tinggi suhu di wilayah maka semakin menuruh kejadian DBD (Ariati dkk, 2014; Handayani, 2012).

Arah hubungan antara suhu dengan kejadian DBD tahun 2004 - 2013 adalah negatif yaitu setiap peningkatan suhu akan menurunkan kejadian DBD. Peningkatan suhu mengurangi waktu yang dibutuhkan bagi virus untuk mereplikasi dan menyebar di nyamuk (Fairos, et al. 2010). Pada kondisi suhu rendah maka pemerintah dan petugas kesehatan lebih waspada untuk peningkatan DBD, kegiatan penyuluhan harus terus dilakukan sehingga masyarakat mengetahui gejala terjadinya penyakit DBD untuk dapat segera mencari pertolongan. Penyakit DBD dapat diobati tetapi jika pertolongan terlambat dapat menyebabkan kematian.

\section{Curah Hujan dengan Angka Kejadian Demam Berdarah Dengue}

Curah hujan rata-rata pada tahun 2004 - 2009 di Kota Tanggerang adalah 175,7 dengan simpangan baku 137,4. Hasil korelasi dan regresi pertahun didapat hubungan yang bermakna antara curah hujan dengan kejadian DBD pada tahun 2004, 2006, 2011, 2013 dan periode 10 tahun (2004 - 2013) dengan nilai $\mathrm{p}=0,000$, koefisien korelasi yang sedang $(\mathrm{r}=0,355)$ dan koefesien determinasi 0,126 yaitu bahwa dapat dijelaskan $12,6 \%$ kejadian DBD disebabkan oleh curah hujan, dengan arah hubungan yang positif, yaitu semakin tinggi curah hujan maka tinggi pula kejadian DBD. Temuan ini sama senada dengan yang terjadi di Sumatera Utara yang menggunakan time lag 0-2 bulan (Fazidah et al, 2015). Peningkatan curah hujan akan diikuti dengan penurunan suhu dan peningkatan kelembaban. Hujan yang turun akan menurunkan suhu udara sehingga kandungan uap air diudara semakin banyak yang menyebabkan kelembaban nisbi udara meningkat. DBD menunjukkan pola yang berkaitan dengan iklim terutama curah hujan karena mempengaruhi penyebaran vektor nyamuk dan kemungkinan menularkan virus dari satu manusia ke manusia lain (Sia, 2008). Arah hubungan antara curah hujan 
dengan kejadian DBD pada tahun 2004 - 2013 adalah positif yang artinya bahwa setiap peningkatan curah hujan akan meningkatkan kejadian DBD.

Populasi Ae. aegypti tergantung dari tempat habitat perkembangbiakan, dengan curah hujan yang tinggi dan berlangsung dalam waktu yang lama dapat menyebabkan kontainer menampung genangan air seperti bak mandi, kaleng bekas, ban bekas, pot bungga, dan lain-lain yang ada di lingkungan sehingga meningkatkan jumlah vektor dan menyebabkan meningkatnya frekuensi vektor mengigit manusia dan terjadi peningkatan kejadian DBD, hal ini sejalan dengan kejadian yang terjadi di Jakarta Timur pada tahun 2000 - 2009 dimana curah hujan akan menambah genangan air yang akan digunakan sebagai habitat bagi nyamuk untuk berkembangbiak.

Dengan tersedianya habitat yang baik maka nyamuk akan bertambah banyak dan resiko penularan akan semakin tinggi (Febriasari 2011). Hasil penelitian di kota Dhaka, Bangladesh menunjukkan bahwa curah hujan, suhu maksimum dan kelembaban relatif secara signifikan berkorelasi terhadap terjadinya infeksi dengue di kota Dhaka. Meskipun model prediksi memiliki beberapa keterbatasan dalam memprediksi jumlah bulanan kasus demam berdarah, yang dapat memperkirakan kemungkinan wabah dua bulan sebelumnya dengan akurasi yang cukup besar (Karim et al, 2012; Islam et al, 2018). Pada saat curah hujan tinggi maka melakukan $3 \mathrm{M}$ yaitu menguras, menutup, dan mengubur kointener yang menampung genangan air harus dilakukan masyarakat dalam hal ini petugas kesehatan dapat memberikan sosialisasi kepada masyarakat.

\section{Kelembaban dengan Angka Kejadian Demam Berdarah Dengue}

Kelembaban rata-rata pada tahun 2004 - 2013 adalah 79,9\% dengan simpangan baku 4\%. Usia nyamuk betina mencapai 104 hari, jika dilihat dari kelembaban pertahun maka kelembaban rata - rata tertinggi ada pada tahun 2005 yaitu 82,4\% dengan jumlah kasus DBD rata - rata 42,1 (bukan kasus yang tertinggi) hal tersebut bertentangan dengan teori bahwa kelembaban tinggi akan menyebabkan umur nyamuk mencapai umur maksimal sehingga kejadian demam berdarah meningkat. Dengan menggunakan seasonal autoregressive integrated moving average model untuk mengetahui hubungan kelembaban dengan kejadian DBD pada tahun 2000 - 2006 di Guadeloupe pada time lag 7 minggu didapat hubungan yang bermakna $(p=0,02)$ (Gharbi, 2011).

Arah hubungan kelembaban dengan kejadian DBD adalah positif yaitu setiap peningkatan kelembaban akan meningkatkan kejadian DBD, dan koefisien korelasi 0,298, yang menandakan hubungan yang sedang. Pham et al (2011) di Vietnam juga menemukan hal yang sama yakni kelembaban yang tinggi berhubungan dengan tingginya angka demam berdarah.

Kelembaban udara tidak berpengaruh langsung pada angka kejadian DBD, tetapi berpengaruh pada umur nyamuk Ae. aegypti. Pada kelembaban udara yang rendah yaitu dibawah $60 \%$ terjadi penguapan air dari tubuh nyamuk sehingga dapat memperpendek umur nyamuk dan tidak bisa menjadi vektor karena tidak cukup waktu untuk perpindahan virus dari lambung ke kelenjar ludah. Sedangkan jika kelembaban tinggi (> 85\%) maka umur nyamuk bertambah dan penyebaran penyakit DBD pun meningkat. Kondisi ini sama dengan kejadian di Jakarta Timur pada pengamatan tahun 2000 - 2009 dimana kelembaban memiliki hubungan dengan kejadian demam berdarah dengue di Jakarta Timur yaitu pada tahun 2004 dan tahun 2006, pada tahun 2006 didapati kenaikan kasus yang signifikan meskipun kelembaban tidak tinggi karena tahun sebelumnya (2005) didapati jumlah kasus yang tinggi (Febriasari, 2011). 


\section{PENUTUP}

Terdapat hubungan yang bermakna dan koefisien korelasi yang sedang pada variabilitas iklim yaitu suhu, curah hujan dan kelembaban terhadap kejadian DBD periode 10 tahun (2004 - 2013). Semakin tinggi suhu di wilayah maka semakin menurun kejadian DBD, semakin tinggi curah hujan maka tinggi pula kejadian DBD (arah hubungan yang positif), dan kelembaban tinggi akan menyebabkan kejadian demam berdarah meningkat. Disarankan kepada pemerintah dan petugas kesehatan melalui kader tiap rukun tetangga (RT) dapat melakukan kegiatan penyuluhan untuk mengetahui tindakan $3 \mathrm{M}$ yaitu menguras, mengubur, dan menutup kointener tempat genangan air, serta cara penanganan apabila sudah terkena DBD sehingga dapat ditolong dengan cepat.

\section{DAFTAR PUSTAKA}

Ariati, Jusniar, Nawar A. 2014. Model Prediksi Kejadian Demam Berdarah Dengue (DBD) berdasarkan Faktor Iklim di Kota Bogor, Jawa Barat. Bul. Penellitian Kesehatan. 42(4): 249 - 256.

Arieskha FT, Rahardjo M, Joko T. 2019. Variabilitas Cuaca Dan Asosisasinya dengan Kejadian Demam Berdarah Dengue Di Kabupaten Tegal. Jurnal Kesehatan Lingkungan. 11(4): 339-347.

Dinas Kesehatan Provinsi Banten. 2018. Profil Kesehatan Provinsi Banten. Banten: Dinas Kesehatan Provinsi Banten.

Dinas Kesehatan Provinsi Banten. 2019. Profil Kesehatan Provinsi Banten. Banten: Dinas Kesehatan Provinsi Banten.

Fairos WY, Wan WH, Wan AL, Alias M, Bee WY. 2010. Modelling Dengue Fever (DF) and Dengue Haemorrhagic Fever (DHF) Outbreak Using Poisson and Negative Binominal Model. World Academy of Science, Engineering and Technology. 62.

Febriasari SG. 2011. Perubahan Iklim dengan Kejadian Penyakit Demam Berdarah dengue (DBD) di Kota Administrasi Jakarta Timur Tahun 2000 - 2009. (Skripsi). Universitas Indonesia. Jakarta.

Gharbi M. 2011. Time Series Analysis of Dengue Incidence in Guadeloupe, French West Indies: Forecasting Models using Climate Variables as Predictors. BMC Infectious Diseases.166(11): 1471 - 2334.

Handayani P. 2012. Hubungan antara Faktor Iklim dan Kejadian Demam Berdarah Dengue (DBD) di wilayah DKI Jakarta Tahun 2008 - 2011. (Skripsi). Universitas Indonesia. Jakarta.

Ibarra SA and Lowe R. 2013. Climate and Non-Climate Drivers of Dengue Epidemics in Southern Coastal Ecuador. Am J Trop Med Hyg. 8(5): 971981.

Indrayani, Yoeyoen A, Wahyudi T. 2018. Situasi Penyakit Demam Berdarah di Indonesia Tahun 2017. Pusat Data dan Infromasi Kemeterian Kesehatan RI. Jakarta.

Karim, Nazmul MD, Munshi SU, Anwar N, Alam MD. 2012. Climatic Factors Influencing Dengue Cases in Dhaka City: A Model for Dengue Prediction. The Indian Journal of Medical Research. 136(1): 32 - 39.

Islam MZ, Rutherford S, Phung D, Uzzaman MD, Baum S, Huda MM, Asaduzzaman M, Talukder MRR, Chu C. 2018. Correlates of Climate Variability and Dengue Fever in Two Metropolitan Cities in Bangladesh." Cureus. 10(10): 3398.

Pham HV, Doan HT, Phan T, Minh NN. 2011. Ecological Factors Associated with Dengue Fever in a Central Highlands Province, Vietnam. BMC Infect, Vol. 11: $1471-2334$. 
Raksanagara A, Arisanti N, Rinawan F. 2015. Dampak Perubahan Iklim Terhadap Kejadian Demam berdarah di Jawa Barat. Jurnal Sistem Kesehatan. 1(1): $43-47$.

Sangkertadi. 2013. Kenyamanan Termis di Ruang Luar Beriklim Tropis Lembab. Alfabeta. Bandung.

Sia S. 2008. Correlation of Climate Factors and dengue incidencein Metro Manila, Philiphines, Ambio. A journal of the human environment. 37(4): $292-294$.

Fazidah SA, Abdullah MR, Omar J, Sarumpaet SM. 2015. Climate Variability and Disease Forecasting Model for Dengue Hemorrhagic Fever in North Sumatera Province, Indonesia. Research Journal of Medical Sciences. 9 (2): $18-27$.

Suhardi B. 2012. Buku Informasi Perubahan Iklim dan Kualitas Udara di Indonesia. Badan Meteorologi dan Giofisika. Jakarta. 